\title{
An Application on the Relationship between Postmodern Organization Approach and Employee Innovation: Kırıkkale Municipality Case
}

\author{
AKYAY UYGUR \\ Prof. Dr. Ankara Hacı Bayram Veli Üniversitesi, Turizm Fakültesi, Ankara, Turkey. \\ Email: akyay.uygur@hbv.edu.tr \\ BETÜL AKYOL \\ Phd Student Ankara Hacı Bayram Veli Üniversitesi, Turizm Fakültesi, Ankara,Turkey. \\ Email: betul.akyol@hbv.edu.tr
}

\begin{abstract}
Innovation in an organization is the most important determinant of successful performance and long-term survival. This study aims to reveal the relationship between postmodern organizational approach and employee innovation. A questionnaire technique was used in this study on 130 employees in Kirlkkale Municipality. The data obtained were analyzed through SPSS (Statistical Program for Social Sciences) package program. Correlation analysis was conducted to investigate the relationship between postmodern organizational approach and employee innovation. According to the findings, there was a significant relationship between postmodern organizational approach and employee innovation. However, it was found that there is a negative relationship between gender, postmodern organization approach, and the effect on employee innovations. It is determined that there is a very weak and negative relationship between the place of residence, postmodern organization approach and the effect on the innovation of employees. It found that there was a very weak relationship between the working year, postmodern organizational approach and its impact on employee innovation. In addition, chi-square and Kruskal-wallis tests were performed.
\end{abstract}

Keywords: Modernism, Postmodern Organization Approach, Innovation, Production Innovation, Process Innovation, Municipality of Kırlkkale.

\section{Introduction}

Innovation in the 21 st century and postmodernity must be adopted to succeed in strong global economies. The postmodern world is filled with increasing rate of change, global competitiveness, information and electronic revolution, and an unpredictable environment. Flexibility and organizational response gain importance (Lonar, 2005:110). Postmodern approach has developed quality circles, project groups, new methods and techniques of doing business in contemporary organizations and has created new and more diversified products. Postmodern organizations have structural characteristics identified by post-industrial society or post-fordism. Postmoodern organizations employ differentiated structures, niche marketing strategies, highly skilled workers and make extensive use of flexible production systems. Postmodernism should focus on organizational production rather than production organization (Harlander, 2018). Innovation has become an important issue on the global economic growth and sustainability agenda (Schacter, 2018:65). Change is everywhere and widespread. Innovation facilitates the adaptation process to many of these changes. The ability of companies to develop new technologies is central to their strategic 
competitiveness. Therefore, the only way for a company to maintain its competitive advantage is to continuously increase its features and activities through innovation. Economists see innovation as a new product, process and application that is to the industry. On the other hand, organizational theorists define innovation for company as a new product, process or application. It emphasizes the speed of innovation or the speed of a firm in accessing and using innovation compared to other firms in a sector (Gopalakrishnan,2000:137).

Today's organizations want creative and new ideas from employees who can contribute to innovation performance. The individual engaged in creative activities has the chance to develop his / her competencies and skills. Employees who exhibit innovative behavior are more likely to promote reward and promotion. Moreover, the innovation of employees affects their social networks and social status. There is a demand for innovative employees by organizations and every organization tries to keep innovative people in their hands (Dedahanov vd. 2017,336).

The study is an application on the relationship between postmodern organizational approach and employee innovation. Since there is no study examining the relationship between postmodern organizational approach and employee innovation, this study is important in terms of filling the gap in the literature.

\section{The Modernism Concept}

The foundation of modernism was laid in the 17 th and 18th centuries, the concept of modernism, which has been used in all areas of life until the middle of 21.century the world, comes from the Latin word modo, result from modernus. Modernism means modernization according to Tdk (Turkish Language Society) institution. Modernism, the routine of daily life, the weakening of belief in religious values, the differentiation and individualization of lifestyles, the rise of urbanization, the placement of science and technique in all areas of life, capitalism can be expressed as an endless movement on economic life. This shows that modernism exists in every moment of life (Kırılmaz ve Ayparçası, 2016:33).

The concept of modernism, which was used in the first West in the 18th century with the Age of Enlightenment, developed with the modern capitalist-industrial structure, did not accept the traditional order, economic, social and administrative structures are differentiation. However, economic and political forces interfere with daily life and distort communication, and that the individual happiness promised by enlightenment is not realized. Defined as critical modernism, pioneered by Descartes and Kant, this approach has been extended to systematic modernism, in which the laws of nature, which Saint Simon and August Comte consider as the sole absolute truth, are instrumentalized in the attempt to adapt to the functioning of society. Durkheim and Weber's approach to division of labor and bureaucracy, followed by Parsons and Merton's structural - functionalist contributions, laid the foundations for a modern society (Erdemir ve Koç,2010:27).

The main modern thesis on organizations was put forward by Max Weber's study. The modernity of modern organizations stems from Weber's bureaucracy. Weber and his followers presented bureaucratic organizations as one of the greatest achievements of modernism. Weber's bureaucracy has meticulously isolated politics, technocrat, the best single way, and has justified its actions with the principles of scientific of administration. This demand for reality of modernism is of utmost importance as it is a fundamental discourse on the construction and flow of modern social life, rather than its methodological dimension. In this context, bureaucracies are the administrative spaces where the experience of modernism is lived (Y1ldirım,2009: 385).

\section{Postmodern Organization Approach}

The beginning of the postmodern era generally arose in the time of "divided into various networks brought together by information technology" traditional economic and social organizations of the nation state. The 
postmodern era is characterized by rapid transitions in economic, political and social sectors (Beckerman,1999:180).

Objective epistemology and methods were criticized by researchers who emphasized subjectivity. However, these researchers were careful to remain within the modernist framework. In the meantime, the paradigm debates that emerged in the philosophy of science were also reflected in organizational theory. By the 1980s, postmodernism became a debate in the social sciences. The postmodern approach began to gain a place in organizational theory and research since the 1990s. Postmodernism speaks of the relativity of knowledge, rather than a single, universal mind. Instead of regularity, continuity and logic, it draws attention of contradiction, uncertainty, transience, chaos and confusion. Postmodernism is looking for signs that society has entered a new era. A number of innovations that are thought to have emerged as a result of developments in communication technologies are identified with postmodernism of the period. The modern organization is bureaucratized in the Weberian sense and has rationalism based on mechanical control structures. In contrast, new forms of business organization in Japan, Sweden, Italy and the Far East, based on relatively small-scale, flexible production, multi-skilled workforce, widespread use of information technology, decentralized and participatory management, an organized in networks or networks, are emerging postmodern organizations is described (Sargut ve Özen, 2007:379-385).

He argues that postmodern organizations should be reactive by nature and invite problem-solving strategies triggered by local interpretations rather than central planners. Hence the hierarchy in postmodern organizations is supported by human networks that come together for a particular purpose and are disassembled and reorganized into new configurations to overcome new tasks. Networking, based on specific tasks or objectives, requires organizational localization that has an impact on small, temporary operations units. In order to develop closer relationships with consumers, postmodern organizations often seek consumer input to convert passive consumers into active participants (Beckerman,1999:182).

The postmodern world is filled with increasing pace of change, global competitiveness, information and electronic revolution, turbulent and unpredictable environments. Flexibility and organizational sensitivity gain importance in the postmodern organization. Teamwork, cross-training, job switching, outsourcing, conditional employment contracts. Organizations come to the forefront and information technology enables communication everywhere. Moreover, institutions are striving for decentralized structures where employees are more empowered. Gaining "the right" size in terms of number of employees and asset value. The "just in time" system tends to reduce inventory costs. Production is attracted by market demand, rather than pushed by the internal-status principle. Postmodern organization is defined by fuzzy and variable boundaries. This is driven by alliances, networks, joint ventures between different firms, as well as increased volatility in labor conditions. The flattening of the structure brings numerous layoffs that increase employee insecurity and accelerate business competition. Thereafter, the number of workers hired temporarily experienced a rapid increase (Lonar,2005:109).

\section{The Innovation Concept}

The concept of innovation was first mentioned in Schumpeter 'The Theory of Economy Development, and it emerged from the economic, commercial and industrial structure of capitalist industrialization (1934). Innovation, on the other hand, was only related to production in developed countries in the 1960s, and it was related to technology-based R \& D activities developed by large companies and patenting. According to Schumpeter, innovation is a new product, process / production method, a new market / supply source, a new form of business or organization (Schumpeter,1934). According to Damanpour (1996), innovation is defined, including new products or services, new process technologies, new organizational structures or administrative systems, or new plans and programs for members of the organization. In other words, it is perceived as a means of changing an organization, as a response to changes in the external environment, or as an action affecting the environment (694). 
It is the realization of a new or significantly improved product (product or service), or process, a new marketing method or a new organizational method in in-house applications, workplace organization or external relations. It can be developed for the first time or includes products, processes and methods that they have adapted from other institutions (OECD ve Eurostat, 2005:50).

The invention, innovation and change define the nature of innovation. Innovation is not only technological but also social, cultural, corporate inclusive, green, eco, open, user-oriented, simple, low cost, public and transformative. It is considered both the process and the result of creating or inventing something new and valuable that has wider impacts on economic and technological developments (Schacter, 2018:65).

An organization innovates to adapt to changes in its environment or to influence the environment. Innovation is therefore a response to both internal and external change and a preventive action to change the environment. Innovation is an attempt to create a purposeful, focused change in the economic or social potential of an enterprise. Organizations operating under conditions of severe global competition, rapid technological developments and scarcity of resources need to strive to grow, be effective and even survive. Therefore, developing innovation remains a major challenge for business executives. Innovation is understood and examined both as a process and as a result. Understanding innovation as a process; a new idea or behavior needs to be created, developed, implemented and ultimately terminated. Understanding innovation as an outcome is an action and program that must be adopted by an organization (Damanpour, 1996:150).

There are two approaches to innovation in organizations: This is because it can be produced and adopted / adapted. Innovation is often produced in organizations for their own use and for sale to other organizations. Innovation production is a process that emerges as a result (a new product, service, program or technology). The result produced by another organization undergoes this result of another organization, that is, the process of adopting innovation in its own organization. For the producing organization, the innovation process involves the idea of generating ideas, project definition, design and development of the product or service, and marketing and commercialization. The innovation process for the adopting organization includes innovation awareness, attitude formation, evaluation, adoption decision, trial implementation and continuous implementation. Innovation can therefore be seen as both a process and a product or service. While the production process leads to innovation as a result for the productive organization; explain how this result is assimilated by the adopting organization during the adoption process. Therefore, we define innovation as the adoption of a new idea or behavior for the organization (Damanpour ve Gopalakrishnan,1998:3).Innovation includes: Product Innovation, Process Innovation, Organizational Innovation.

\section{- Product Innovation}

Product innovation is the most popular type of innovation. Product innovation is defined to potential users as a new or significantly modified product in terms of its properties or intended use. Emphasizes the internal interaction between product and process innovations resulting from the implementation of a new and significantly modified production or delivery process with significant changes in infrastructure and techniques within the organizational unit(Schacter, 2018:69).

\section{- Process Inovasyonu}

Process innovation is a process to achieve input materials, task characteristics, business and information flow mechanisms and lower costs and higher product quality in an organization's production or service operations. Implementation of new or significantly improved production management and techniques may involve changes in equipment or organization. Marketing methods to improve organizational productivity are also components of process innovation. Process innovation in enterprises includes a wide range of new material-process technologies starting with the emergence of design thinking and lean thinking, as well as 
new business practices in human resource coordination. Process innovation is the new methods that organizations can adopt to innovate with limited resources in order to accelerate the speed of technological development (Schacter, 2018:70).

\section{- Organizational Innovation}

The relationship between organization and innovation is complex, dynamic and multi-level. Organizational creation is essential for the innovation process. Innovation is part of the system that produces it. The system itself is an organization or organizational. Organizational innovation means the creation or adoption of a new idea or behavior for the organization. An organization's ability to innovate is a form for the successful use of creative resources and new technologies. The introduction of new technologies often presents complex opportunities and challenges for organizations. This leads to changes in managerial practices and the emergence of new organizational forms (Lam, 2004:3). Organizational innovation deals with changes in organizations. Such changes may occur in organizational structure, new forms of management and work environments (Kahn,2018:457).

Innovation types, quality and quantity of organizations depend on both internal and external environments. Changes in the external environment accelerate innovation in organizations. Organizations' innovation concepts and products are spread to the external environment. Innovation study an accumulation of knowledge has been formed between the two environments in both economic and strategic management studies. Internal environment is typically defined by organizational structure, resources, climate and culture. Resources of an organization's finance, equipment, expertise and so on in terms of what it has. The climate determines what happens and how things happen in an organization and culture, explains why things happen ( Tang, 1998:301).

\section{Research Methodology}

\section{Objectives of the Study}

The aim of this study is to examine the postmodern organizational approach of employees in Kirikkale Municipality is a significant relationship between innovation. For this purpose, the hypothesis of the research is as follows:

$\mathrm{H}_{1}$ : There is a significant relationship between postmodern organizational approach and employee innovation.

$\mathrm{H}_{2 \mathrm{a}}$ : There is a significant relationship between gender, postmodern organizational approach, its effect on employee innovation.

$\mathrm{H}_{2 \mathrm{~b}}$ : There is a significant relationship between the place of residence, the effect of postmodern organizational approach on the innovation of employees.

$\mathrm{H}_{2 \mathrm{c}}$ : There is a significant relationship between working year, postmodern organizational approach, its effect on employee innovation.

\section{Population and Sample}

The population of the study consists of 200 people working in Kirlkkale Municipality in 2018-2019 (www.kirikkale-bld.gov.tr). A sample is a set of units or elements that are capable of representing the universe, selected by any suitable method from within the research universe (Toy ve Tosunoğlu ,2007:6). There are two groups of sampling methods. Probable sampling and non-probability sampling (Arıkan,2017:120). In our study, simple probability sampling, one of the probable sampling methods, was used. Yamane (2001) formula was used to calculate the number of samples. A questionnaire was applied to 130 people. 


\section{Data Collection Method}

Questionnaire technique was used to obtain data. The questionnaire consists of two parts. The first part is composed of 16 expressions related to postmodern organization approach by making necessary literature reading and searching, in the second part, 8 statements related to the concept of innovation were used in the Arikan (2008) questionnaire. The remaining six statements consisted of employees' demographic characteristics. The survey consists of 33 statements in total. The respondents were asked to mark the likert type $(1=$ Strongly disagree $2=$ Disagree $3=$ Neither agree or disagree $4=$ Agree 5=Strongly agree) 5-point rating. The pilot study was conducted with 24 people. In the pilot study, reliability analysis was performed. As a result of the calculation, the cronbach alpha coefficient is 0.972 . The reliability level is satisfactory. The data obtained from the questionnaires were analyzed by SPSS (Statistical Program for Social Sciences). Correlation analysis was performed for the hypothesis test.

\section{Findings and Evaluations}

Table 1: Findings on Demographic Characteristics of Participants

\begin{tabular}{|c|c|c|c|}
\hline Demographic & Groups & (f) & $(\%)$ \\
\hline \multirow{2}{*}{ Gender } & Male & 74 & 56,9 \\
\hline & Female & 54 & 43,1 \\
\hline \multirow{2}{*}{ Residing } & Rural City & 111 & 85,4 \\
\hline & Urban City & 19 & 14,6 \\
\hline \multirow{3}{*}{ Education } & High School & 48 & 36,9 \\
\hline & $\begin{array}{c}\text { Vocational High } \\
\text { School }\end{array}$ & 37 & 28,5 \\
\hline & $\begin{array}{c}\begin{array}{c}\text { Bachelor's } \\
\text { degree }\end{array} \\
\end{array}$ & 38 & 29,2 \\
\hline \multirow{3}{*}{ Education } & Master's degree & 4 & 3,1 \\
\hline & Phd & 2 & 1,5 \\
\hline & Other & 1 & 0,8 \\
\hline \multirow{5}{*}{ Age } & 25 and under & 24 & 18,5 \\
\hline & $26-35$ & 46 & 35,4 \\
\hline & $36-45$ & 39 & 30,0 \\
\hline & $46-55$ & 17 & 13,1 \\
\hline & $56-65$ & 4 & 3,1 \\
\hline \multirow{4}{*}{ Job } & Officer & 84 & 64,6 \\
\hline & Engineer & 5 & 3,8 \\
\hline & Worker & 37 & 28,5 \\
\hline & Administrator & 4 & 3,1 \\
\hline \multirow{7}{*}{$\begin{array}{c}\text { Working } \\
\text { year }\end{array}$} & $1-5$ year & 48 & 36,9 \\
\hline & 5-10 year & 32 & 24,6 \\
\hline & $10-15$ year & 22 & 16,9 \\
\hline & 15-20 year & 15 & 11,5 \\
\hline & 20-25 year & 7 & 5,4 \\
\hline & 25-30 year & 3 & 2,3 \\
\hline & 30 and above & 3 & 2,3 \\
\hline
\end{tabular}

When the gender distribution of the participants in Table 1 is analyzed, the participants are male $56.9 \%$ (74persons) and $43.1 \%$ (54persons) women. When the place of residence of the participants is examined, $85.4 \%$ (111 people) live in rural cities and 14.6\% (19 people) live in urban cities. According to the educational level of the participants, $36.9 \%$ (48 people) of high school, $28.5 \%$ (37 people) of vocational 
high school, 29.2\% (38 people) of bacholar's degree, 3.1\% (4 people) of master's degree, 1.5\% (2 people) of phd, the other, \%0,8(1 person) of other is consisted. When the age levels of the participants are considered 25 and under age 18.5\% (24people), 26-35age 35.4\% (46people), 36-45 age \% 30.0 (39people), 46-55 age \% 13.1 (17people), 56- 65\% consists of 3.1\% (4 people). When the task levels of the participants are analyzed, officer $64.6 \%$ (84 people), engineers, $3.8 \%$ (5 people), workers $28.5 \%$ (37 people), administrator $3.1 \%$ (4 people). Looking at the working years of the participants, 1-5 years $36.9 \%$ (48 people), 5-10 years $34.6 \%$ (32 people), 10-15 years $16.9 \%$ (22 people), 15-20 years 5.4\% (7 people) ), 2530 years consists of $2.3 \%$ (3 people).

Table 2: The Relationship Between Postmodern Organization Approach and Innovation of Employees

\begin{tabular}{|cccc|}
\hline & & Innovation & $\begin{array}{c}\text { Postmodern Organization } \\
\text { Approaches }\end{array}$ \\
\hline & $\mathrm{r}$ & 1 &, $865^{* *}$ \\
\cline { 2 - 4 } Innovation & $\mathrm{p}$ & - &, 000 \\
\hline $\begin{array}{c}\text { Postmodern Organization } \\
\text { Approaches }\end{array}$ & $\mathrm{r}$ &, $865^{* *}$ & 1 \\
\cline { 2 - 4 } & $\mathrm{p}$ &, 000 & - \\
\hline $\mathrm{p}<0,01(2$ tailed $)$ & & &
\end{tabular}

Correlation analysis between postmodern organizational approach and its impact on the innovations of employees in Kirıkkale Municipality was conducted. Before the correlation analysis, 15 statements indicating postmodern organizational approach were averaged and 11 statements indicating innovation were averaged. Correlation analysis result shows whether there is a linear relationship with the correlation coefficient ( $r$ ). It takes values between -1 and +1 . If the correlation coefficient is +1 , there is an excellent positive linear relationship between variables, and -1 is an excellent negative linear relationship between variables, and a correlation coefficient of 0 indicates that there is no linear relationship between variables (Kalayc1, 2008:117). According to the results of correlation analysis, $H_{1}$ : There is a significant relationship between postmodern organizational approach and employee innovation. The hypothesis was accepted.

Table 3:Demographic Characteristics (Gender, Place of Residence, Working Year), Relationship Between Postmodern Organization Approach and Innovation of Employees

\begin{tabular}{|cccc|}
\hline & & Innovation & $\begin{array}{c}\text { Postmodern Organization } \\
\text { Approaches }\end{array}$ \\
\hline \multirow{2}{*}{ Gender } & $\mathrm{r}$ &,$- 264 * *$ &,$- 255^{* *}$ \\
\cline { 2 - 4 } & $\mathrm{p}$ &, 002 &, 003 \\
\hline Place of Residence & $\mathrm{r}$ &,- 023 &, 022 \\
\cline { 2 - 4 } & $\mathrm{p}$ &, 795 &, 807 \\
\hline $\begin{array}{c}\text { Working } \\
\text { Year }\end{array}$ & $\mathrm{r}$ &, 020 &, 006 \\
\hline${ }^{*}<0,01(2$ tailed $)$ & $\mathrm{p}$ &, 821 &, 948 \\
\hline
\end{tabular}

Pearson correlation coefficient (r) 0.00-0.25 very weak, 0.26-0.49 weak, 0.50-0.69 medium, 0.70-0.89 high, 0.90-1.00 very high is expressed as (Kalayc1,2008:116). As a result of the correlation analysis, $\mathrm{H}_{2 \mathrm{a}}$ : There is a significant relationship between gender, postmodern organizational approach, its effect on employee innovation. There is a negative relationship between gender, postmodern organizational approach and the impact on the innovations of employees. $\mathrm{H}_{2 \mathrm{a}}$ rejected.

$\mathrm{H}_{2 \mathrm{~b}}$ : There is a significant relationship between the place of residence, the effect of postmodern organizational approach on the innovation of employees. As a result of the correlation analysis, it is found 
that there is a negative and very weak relationship between the place of residence, postmodern organization approach and the impact on the innovations of employees $\mathrm{H}_{2 \mathrm{~b}}$ rejected.

$\mathrm{H}_{2 \mathrm{c}}$ : There is a significant relationship between working year, postmodern organizational approach, its effect on employee innovation. As a result of the correlation analysis, it was found that there is a very weak relationship between the working year, postmodern organizational approach and the impact on the innovations of employees $\mathrm{H}_{2 \mathrm{c}}$ rejected.

Table 4: According to Gender, "Postmodern approach, innovative approaches are given importance in our organization"' Expression Related to Kruskal-Wallis Test

\begin{tabular}{|ccc|}
\hline Gender & Numbers of Unit & Average \\
\hline Male & 74 & 70,73 \\
\hline Female & 56 & 67,91 \\
\hline
\end{tabular}

$\mathrm{H}_{1}$ : There is a statistically significant difference between the participants' gender "Postmodern approach, innovative approaches are given importance in our organization' and their responses to their testimony.

The $\mathrm{H}_{1}$ hypothesis was rejected because the significance value of the Chi-square test was not 0.000 ( $\mathrm{P}$ $<0.05)$. There isn't a statistically significant difference between the participants' gender "Postmodern approach, innovative approaches are given importance in our organization' and their responses to their testimony. Since the $\mathrm{P}$ value is greater than 0.05 , the $\mathrm{H}_{1}$ hypothesis is rejected. As a result of KruskalWallis test, it was observed that males had a higher average than females.

\section{Result}

Innovation is an integral part of postmodernism. Organizations need to manage environmental risks and uncertainties effectively. Since decision-makers don't know much about the environment and there is uncertainty about changes, organizations must constantly propose new ideas for survival. In organizations, inventions and innovation are proposed instead of classical order. According to postmodernism, the lack of relativity and stability, postmodernism can encourage and appreciate innovation management and employees in the planning of key funds. The leader of postmodernism must be creative, inventor and innovative, and guide employees in creativity and innovation( Bazrkar vd. ,2014:2741). Postmodern structures can very well meet the demand for fast and innovative environments, and organizations can add reproduction to their cultural norms (Erbe,2014:35).

Global postmodernist production not only recognizes existing industrial technology, but also promotes and orients nations' innovation activities. In other words, regions or countries that incorporate postmodernist thinking tend to succeed in innovation (Harlander, 2018).

Innovation is of great importance to organizations as it can be the source of additional revenue from new products or services. Helps reduce costs or improve the quality of existing processes. Innovation is used to solve business problems and challenges in organizations, thus providing a pace of survival and success for the organization for the present or future (Zawawi,2016).

The results of this study, which measures the relationship between the postmodern organization approach and the innovation of employees in Kirlkkale Municipality, are important in terms of determining the relationship between the innovation of employees and the postmodern organization approach. It was found that there is a relationship between flexible production, employee participatory, organizational sensitivity, information technology and communication intensive, postmodern organizational approach that emphasizes changes, local interpretation and joint ventures, and employee innovation. In our study, there was no relationship between demographic characteristics of employees, gender, place of residence and working 
year, and postmodern organization approach and employee innovation. It is observed that men have a higher average in the expression that importance is given to innovation through postmodern approach in organizations. In the postmodern world, postmodern organization approach should be given importance and applied rather than classical organization approach in institutions. It is seen that employees contribute to innovation, change and development. Organizations need innovation to sustain and adapt to severe competition.

Employees' organizations with the postmodern approach of this study to examine the relationship between innovation with different results and recommendations made in different institutions in Turkey could be developed.

\section{References}

Arıkan L. Cenk (2008). Evaluation of Dynamic Innovation in Turkey: Innovation Impact on Company Performance, Boğaziçi University Social Sciences Institute Business Administration and Organization (Unpublished $\mathrm{PhD}$ Thesis)

Arıkan R. (2017). Research Methods and Techniques, Nobel Academy Revised 3rd Edition-Ankara

Bazrkar A. , Heravi J. A. and Abedzadeh M. (2004) The Impact of Postmodernizm on Management and Organization Theories, International Journal of Management and Humanity Sciences Volume:3 Number:8 Page: $2739-2743$

Beckerman T. A. (1999). Postmodern Organizational Analysis: An Alternative Framework For School Social Work in Education Cilt:21 Say1:3 Sayfa:177-188 https://watermark.silverchair.com/21-3177.pdf?token=AQECAHi208BE, Reached Date: 14.04.2019

Damanpour F. (1996). Bureaucracy And İnnovation Revisited: Effects Of Contingency Factors, İndustrial Sectors and İnnovation Characteristics, The Journal Of High Technology Management Research", Volume:7 Number:2 Page: 149-173

Damanpour F. (1996). Organizational Complexity and Innovation: Developing and Testing Multiple Contingency Models, Management Science Volume:42 Number:5 Page:693-716

Damanpour F. and Gopalakrishnan S.(1998). Theories of Organizational Structure and İnnovation Adoption: The Role Of Environmental Change, Journal of Engineering And Technology Management Volume:15 Number:1 Page:1-24

Dedahanov T. A. Rhee C. and Yoon J.(2017). Organizational Structure And İnnovation Performance: İs Employee İnnovative Behavior A Missing Link? Career Development International Page:334-350

Erbe D. N. (2014). Approaches to Managing Organizational Diversity and İnnovation, USA

Erdemir E. and Koç U. (2010). Postmodernism and Complexity: A Paradigmatic Discussion in the Context of Organizational Theory, Eskişehir Osmangazi University Journal of Economics and Administrative Sciences Number:1 Page:25-48

Gopalakrıshnan S. (2000). Unraveling The Links Between Dimensions Of Innovation and Organizational Perfermance, The Journal Of High Technology Management Research Volume:11 Number: 1 Page:137-153

Harlander J. (2018). Innovation, Culture and the Path to Postmodernism: Finland, Denmark https://pdfs.semanticscholar.org/d75b/9527ffc73874f646c2d2b7c0ef4fb7283aad.pdf Reached Date: 06.06.2019

Kahn B. K. (2018). Understanding İnnovation, Business Horizons Number:61 Page:453-460

Kalaycı Ş. (2008). SPSS Applied Multivariate Statistical Techniques, 3rd Edition - Ankara

Kırılmaz H. and Ayparçası F. (2016). Reflections of Modernism and Postmodernism on Consumption Culture, Human \&nHuman Number: 8 Page:32-58

Lam A. (2004). Organizational Innovation, Handbook of Innovation Oxford University Editör: Jan Fagerberg, David Mowery, Richard R. Nelson Page: 2-44 
Lonar D. (2005) Postmodern Organization and New Forms Of Organizational Control' Economic Annals no:165 Sayfa: 105-119 www.doiserbia.nb.rs/img/doi/0013-3264/2005/0013-32640565105L.pdf , Reached Date: 14.04.2019

OECD and Eurostat (2005). Oslo Guide: Principles for Collecting and Interpreting Innovation Data 3rd Edition Sayfa:

13-117 http://www.tubitak.gov.tr/tubitak_content_files/BTYPD/kilavuzlar/Oslo_3_TR.pdf Reached Date: 12.05.2019

Sargut S. A. and Özen Ş. (2007) Organization Theories İmge Storebook 1.Edition -Ankara

Schacter E. M. (2018) The Nature And Variety Of İnnovation International Journal of İnovation Studies Number:65-79

Schumpeter A. J. (1934) Theory of Economy Development Third Edition Cambridge file:///C:/Users/pcc/Downloads/9781315135564_googlepreview.pdf Reached Dated: 12.05.2019

Tang H. K. (1998) An İntegrative Model Of İnnovation İn Organizations Technovation Page.297-307

Toy Y. B. and Tosunoğlu G. N. (2007) Scientific Research Process, Statistical Techniques and Errors in Social Sciences Journal of Commerce and Tourism Education Faculty Sayı:1

www.kirikkale-bld.gov.tr ,reached dated: 12.05.2019

Yamane T.(2001) Basic Sampling Methods, Translated by: Alptekin Esin, M. Akif Bakır, Celal Aydın , Esen Gürbüzsel Literature Publications

Yıldırım M. (2009) Modernism, Postmodernism and Public Administration 'International Journal of Human Sciences Volume:6 Number:2 Page:381-397

Zawawi M. F. N. Wahab A. S. Al-Mamun A. Yaacob S. A. Samy K.N. and Fazal A. S. (2016) Defining The Concept of Innovation And Firm İnnovativeness: A Critical Analysis from Resorce-Based View Perspective International Journal of Business and Management Volume:11 Number:6 Page: 87-94.
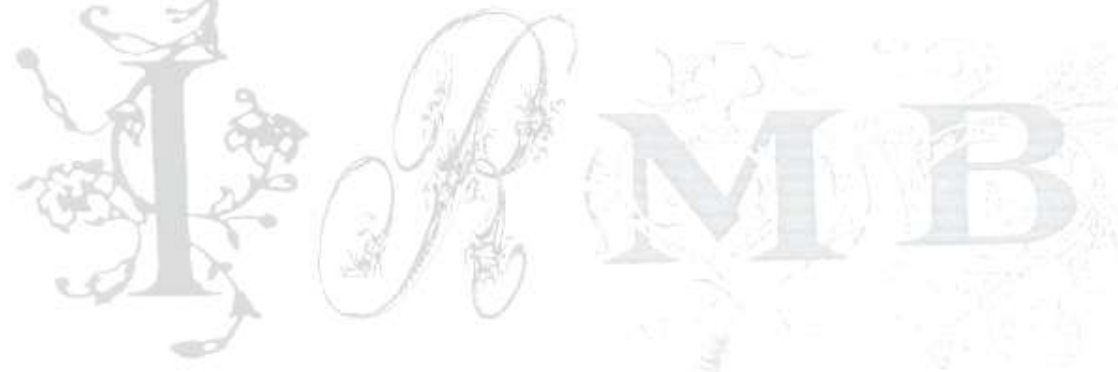